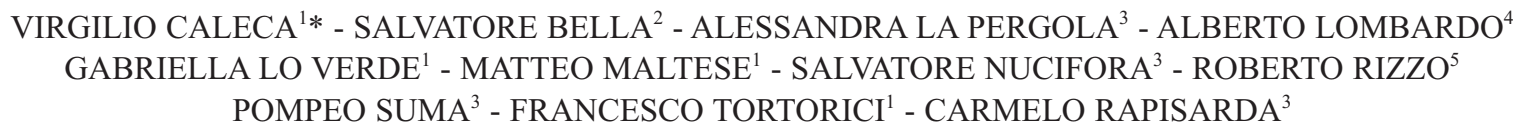

\title{
ENVIRONMENTAL FACTORS IMPACT AND INCIDENCE OF PARASITISM \\ OF PSYLLAEPHAGUS BLITEUS RIEK (HYMENOPTERA ENCYRTIDAE) ON POPULATIONS OF GLYCASPIS BRIMBLECOMBEI MOORE (HEMIPTERA APHALARIDAE) IN MEDITERRANEAN CLIMATIC AREAS $\left({ }^{1}\right)$
}

\author{
$\left({ }^{1}\right)$ Università degli Studi di Palermo, Dipartimento di Scienze Agrarie, Alimentari e Forestali (SAAF), viale delle scien- \\ ze, Edificio 5, 90128, Palermo, Italy. \\ ( ${ }^{2}$ CREA-OFA - Consiglio per la ricerca in agricoltura e l'analisi dell'economia agraria, Centro di ricerca olivicoltu- \\ ra, frutticoltura e agrumicoltura. Corso Savoia 190, 95024 Acireale, Catania, Italy \\ () Università degli Studi di Catania, Dipartimento di Agricoltura, Alimentazione e Ambiente (Di3A), via Santa Sofia \\ 100, 95123, Catania, Italy. \\ $\left({ }^{4}\right)$ Università degli Studi di Palermo, Dipartimento di Innovazione Industriale e Digitale (DIID), viale delle scienze, \\ Edificio 8, 90128, Palermo, Italy. \\ $\left({ }^{5}\right)$ CREA-DC - Consiglio per la ricerca in agricoltura e l'analisi dell'economia agraria, Centro di ricerca Difesa e \\ Certificazione (Research Centre for Plant Protection and Certification), SS.113, Km 245,5, 90011, Bagheria (PA), Italy. \\ *Corresponding author (email: virgilio.caleca@unipa.it)
}

Caleca V., Bella S., La Pergola A., Lombardo A., Lo Verde G., Maltese M., Nucifora S., Rizzo R., Tortorici F., Suma P., Rapisarda C. - Environmental factors impact and incidence of parasitism of Psyllaephagus bliteus Riek (Hymenoptera Encyrtidae) on populations of Glycaspis brimblecombei Moore (Hemiptera Aphalaridae) in Mediterranean climatic areas.

The red gum lerp psyllid, Glycaspis brimblecombei Moore (Hemiptera, Aphalaridae), is an Australian native sapsucking insect pest of eucalypts that has been first reported for the West Palaearctic Region in 2008 and, in 2010, it has been found also in Italy. Subsequently its primary parasitoid, Psyllaephagus bliteus Riek (Hymenoptera: Encyrtidae), was also detected within the main European and North African infested areas, where no release of the parasitoid was ever performed. This study, carried out in 30 Eucalyptus camaldulensis plantations located along the coast, on the hills and the mountains in Mediterranean climatic areas of Sicily (Italy), aimed to determine the influence of environmental parameters on the incidence of both, the psyllid infestation level and the parasitization activity. P. bliteus reached highest average levels in summer samplings and resulted widespread in Sicily at all detected altitudes without statistically significant differences. P. bliteus parasitization is the main factor lowering G. brimblecombei infestation; this result, together with the accidental and contemporaneous arrival of the host and its parasitoid, could explain the absence of high damage level on eucalypts in Sicily. The most significant metric factors positively influencing G. brimblecombei infestation are the percentage of daily hours above $80 \%$ of relative humidity and the average maximum temperature, obviously related to other, but less significant climatic factors. The altitude affects both infestation and parasitization, but single sites could explain significantly more, so that the local conditions where the samplings were carried out have to be considered as the main responsibles for the variability in the obtained results. In any sampled Sicilian site, from sea level to $540 \mathrm{~m}$ a.s.l., both the psyllid and its parasitoids show a good adaptation to climatic conditions, confirming that areas fitting for $E$. camaldulensis growth fit also for P. bliteus activity, and proving that Mediterranean climate, differently from some inland areas of California, does not obstacle its parasitic activity.

KEY WorDS: Red gum lerp psyllid, Sicily, General Linear Model, Relative Humidity, Temperature.

\section{INTRODUCTION}

Glycaspis brimblecombei Moore (Hemiptera, Aphalaridae), commonly known as the red gum lerp psyllid, is an Australian native pest of Eucalyptus trees, which in the last years spread in many other regions.

It was detected outside Australia for the first time in California (USA), in 1998 (GILL, 1998; BRENNAN et al.,

\footnotetext{
${ }^{1}$ Original scientific contribution presented and discussed at the National Symposium on "Health status of Eucalyptus plantations in Italy", Oristano (Centro Congressi Hotel Anfora, Tramatza) - Italy, March 24-25, 2017.
}

1999); afterwards it was found in Hawaii (NAGAMINE and Heu, 2001), Central and South America (Mexico, CIBRIÁN et al., 2001), Chile (SANDOVAL and RothMANn, 2002), Brazil (WiCKen et al., 2003), Argentina (BOUVET et al., 2005), Ecuador (ONORE and GARA, 2007), Venezuela (Rosales et al., 2008), Peru (BURCKHARDT et al., 2008), El Salvador (Jimenez, 2013), Colombia (RodAs et al., 2014) Uruguay (BALDINI et al., 2006), Canary Islands (MALumPhy, 2010), Morocco (BAmI, 2011, IBNELAZYZ, 2011), Algeria (RegUiA and Peris-Felipo, 2013), Tunisia (Ben Attia and RapISARDA, 2014; DHAHRI et al., 2014), Mauritius (SOOKAR et al., 2013), and Madagascar (HoLlis, 2004). From 2008 the psyllid was found in some European countries: Spain and Portugal (HuRTADO and REINA, 2008;), France (COCQUEMPOT 
et al., 2012), Montenegro (MALuMPHY et al., 2013), Greece (Bella and Rapisarda, 2013; Reguia and Peris-Felipo, 2013). In Italy it has been recorded for the first time in Southern and Central regions in 2010 (LAUDONIA and GARONNA, 2010) and new information about pest spread were given by GARONNA et al. (2011) and PERIS-FELIPO et al. (2011). In 2011 it was recorded in Sicily (Lo VERDE et al., 2011), and few months after it was also detected in Sardinia (EPPO, 2011); now it is widespread in the whole country in areas where Eucalyptus camaldulensis Dehnh. is planted.

The host plant, like other species of the genus Eucalyptus, is very common in Italy as ornamental and forest species. As a consequence, serious damage was recorded on eucalyptus trees in parks, urban areas and plantations, and also the Italian beekeepers worried because of the dramatically lower quality and quantity of eucalyptus honey productions (GARONNA et al., 2011; PIBIRI, 2011).

G. brimblecombei is a very aggressive exploiter of resources and for this reason its damage is important; outbreaks have been reported from many countries of South America were the species can cause the death of infested trees, resulting in serious timber production losses (DE QUEIROZ et al., 2012).

The psyllid can be easily detected observing the presence on leaf surfaces of the characteristic white cones (lerps) produced by the nymphs which also serve as shelter until they reach adulthood (HALBERT et al., 2001; BELLA, 2013). In California high population levels are reported to cause leaf fall, a decrease in growth rate, and in some cases death of the infested plant (GILL, 1998; DAHLSTEN et al., 2005); eucalypt mortality rates can reach $15 \%$ in the first year of attack and up to $40 \%$ in the second year if efforts are not made to control the pest (GILL, 1998).

Biological control is a major component of psyllid IPM; nowadays the red gum lerp psyllid seems to be under control after the introduction of the parasitoid wasp Psyllaephagus bliteus Riek (Hymenoptera: Encyrtidae). In the native areas the endemic Psyllaephagus species attack nymphs of Psylloidea, and a few are reported as hyperparasitoids attacking other Psyllaephagus species (RIEK, 1962; NoYES and HANSON, 1996). P. bliteus parasitizes $G$. brimblecombei and other psyllids as: Boreioglycaspis melaleucae Moore on Melaleuca quinquenervia (Cav.) S.T. Blake (Myrtaceae); Creiis costatus (Froggatt), Ctenarytaina eucalypti (Maskell), Glycaspis granulata (Froggatt) and Glycaspis sp. on Eucalyptus spp. (RIEK, 1962; HERTING, 1972; WITHERS, 2001; DAHLSTEN et al., 2002; DAANE et al., 2005; BERRY, 2007). The first classical biological control attempt against $G$. brimblecombei was performed in California collecting $P$. bliteus from its native area (i.e. Australia), then releasing it from the end of 1999 to 2003 (PAine et al., 2000; DAhlsten et al., 2005). P. bliteus has also been deliberately introduced for classical biological control against G. brimblecombei into Mexico (PLASCENCIA et al., 2005) and Chile (IDE et al., 2006).

The arrival of $P$. bliteus in Italy (Sicily: CALECA et al., 2011a; Italian peninsula: LAUDONIA et al., 2014) is due to an accidental introduction, probably together with its host, as also happened in New Zealand, Brazil, Spain, Morocco, Greece, Tunisia, Portugal and Turkey (WITHERS, 2001; Berti-Filho et al., 2003; Berry, 2007; Perez-Otero et al., 2011; BAMI, 2011; Bella and RAPISARDA, 2013; Bella, 2014; DHAHRI et al., 2014; KARACA et al., 2015).

In the framework of an IPM programme, the monitoring activity results highly important to determine the moment of pest population peak, the occurrence of natural enemies and to estimate other factors that can affect the population dynamic.

As it is known, the climatic factors can affect both the pest population density and parasitization level (SANTANA et al., 2003b; Bella and Rapisarda, 2014; FerReira Filho et al., 2015).

Studies conducted in California showed that the pest population suppression by the encyrtids performed better in coastal sites than in inner arid areas, due to the higher summer temperatures herein recorded that reduced the efficacy of the parasitoid activity; still, as psyllid numbers have dropped, the defoliation and death of Eucalyptus trees due to the psyllid have been reduced (DAANE et al., 2005, 2012). In Brazil, a decrease of $G$. brimblecombei population was recorded in the late spring and early summer in function of the rainfall frequency or intensity (DE QUEIROZ et al., 2012).

In Portugal DHAHRI et al. (2014) report how the infestation levels by $G$. brimblecombei were not significantly affected by the different latitudes and longitudes of the studied sites recording also a relatively low parasitism rate.

Recently in Italy, in areas where P. bliteus was absent, it has been suggested that $G$. brimblecombei population size in the new area of colonization is negatively affected by low winter temperatures, but also by high temperatures in the absence of rainfall (LAUDONIA et al., 2014).

In the present paper the distribution and activity of $G$. brimblecombei and P. bliteus in a Mediterranean area, E. camaldulensis plantations distributed in all Sicily, were studied in function of some environmental factors (i.e. altitude and climatic conditions) discussing their importance from an applied point of view.

\section{MATERIALS AND METHODS}

\section{PRELIMINARY SAMPLINGS ON $P$. BLITEUS DISTRIBUTION} IN SICILY

A first preliminary survey on the distribution of $P$. bliteus in Sicily was performed from December 2011 to February 2012 , in order to ascertain the presence of the parasitoid in the whole island. Totally 20 sites have been investigated, most of which along the coast due to the cold period of sampling. Each sample consisted of leaves of E. camaldulensis bearing a total number of at least 100 fully developed lerps. Lerps were analyzed to detect the exit hole of the parasitoid. In the laboratory lerps without a hole were removed counting the number of underlying clearly parasitized hosts (mummies). Psyllid nymphs found on the leaves have been reared at room temperature (for about two weeks) until adults emerged.

\section{SEASONAL SAMPLINGS}

After this preliminary survey that ascertained the presence of $P$. bliteus also in eastern Sicily (Fig. I), widening its distribution in the western areas of the island already stated by CALECA et al. (2011a), data regarding G. brimblecombei infestation level and P. bliteus parasitization level have been collected in Sicilian E. camaldulensis plantations located in areas that fits with the good development of this tree. Thirty sampling sites were chosen from the coast to the interior zones at three altitudinal ranges, as following: 3-52 $\mathrm{m}$ a.s.l. (Coast), 101-356 $\mathrm{m}$ a.s.1. (Hill) and 418-542 $\mathrm{m}$ a.s.1. (Mountain), corresponding to an average yearly temperature in $1965-1994$ of $18-19^{\circ} \mathrm{C}, 17-18^{\circ} \mathrm{C}$ and $16-17^{\circ} \mathrm{C}$ respectively (Fig. II, Tab. 1).

Seven samplings were performed in each site: two in spring 2012 (18-28 Apr.; 30 May-6 Jun.), two in the following summer (12-24 Jul.; 28 Aug.-6 Sep.), two in the following autumn (11-18 Oct.; 27 Nov.-19 Dec.) and the last one in winter 2013 (1-19 Feb.) 


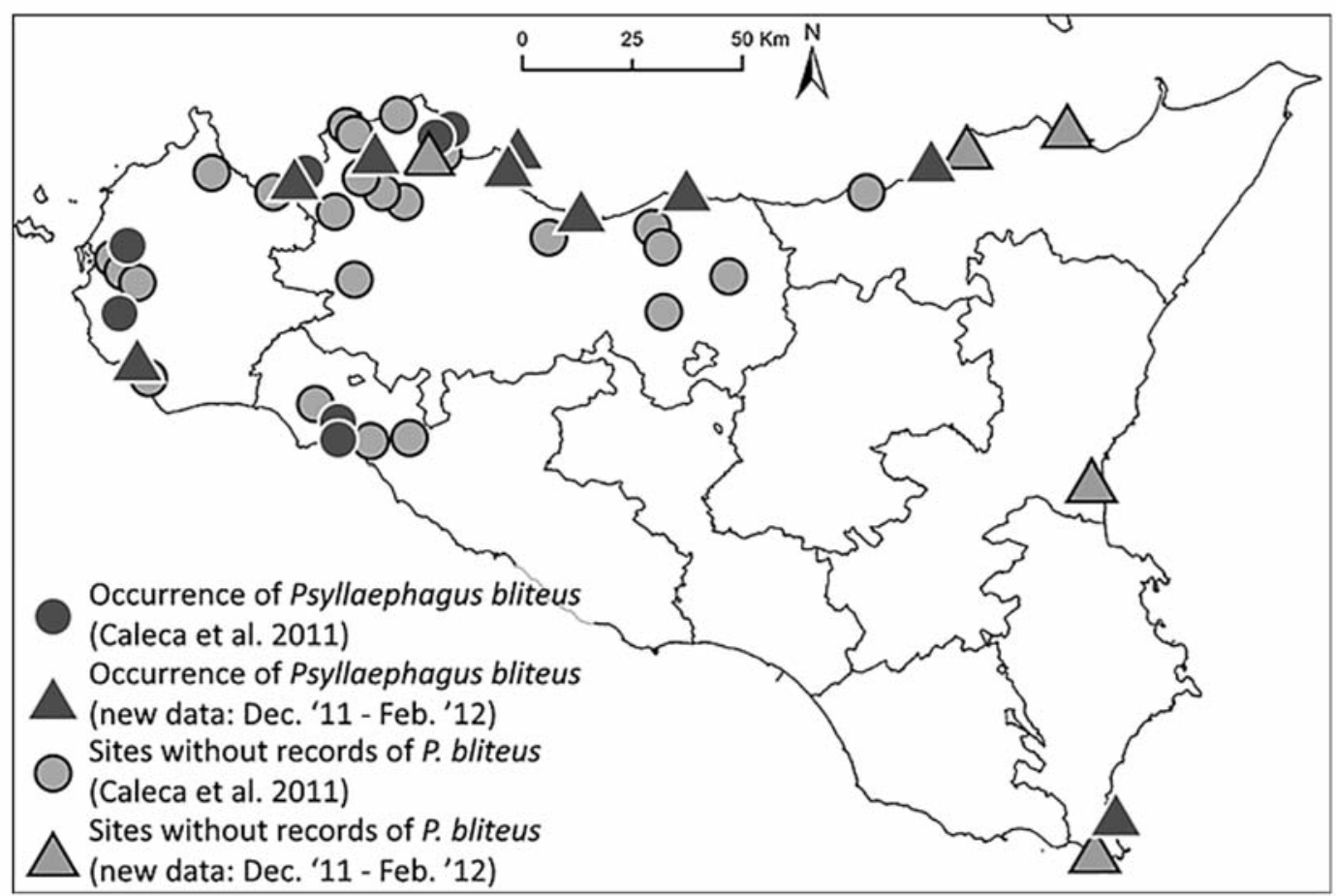

Fig. I - Occurrence of Psyllaephagus bliteus in Sicily, recorded from September 2011 to February 2012 (after CALECA et al., 2011a, modified by addition of new data).

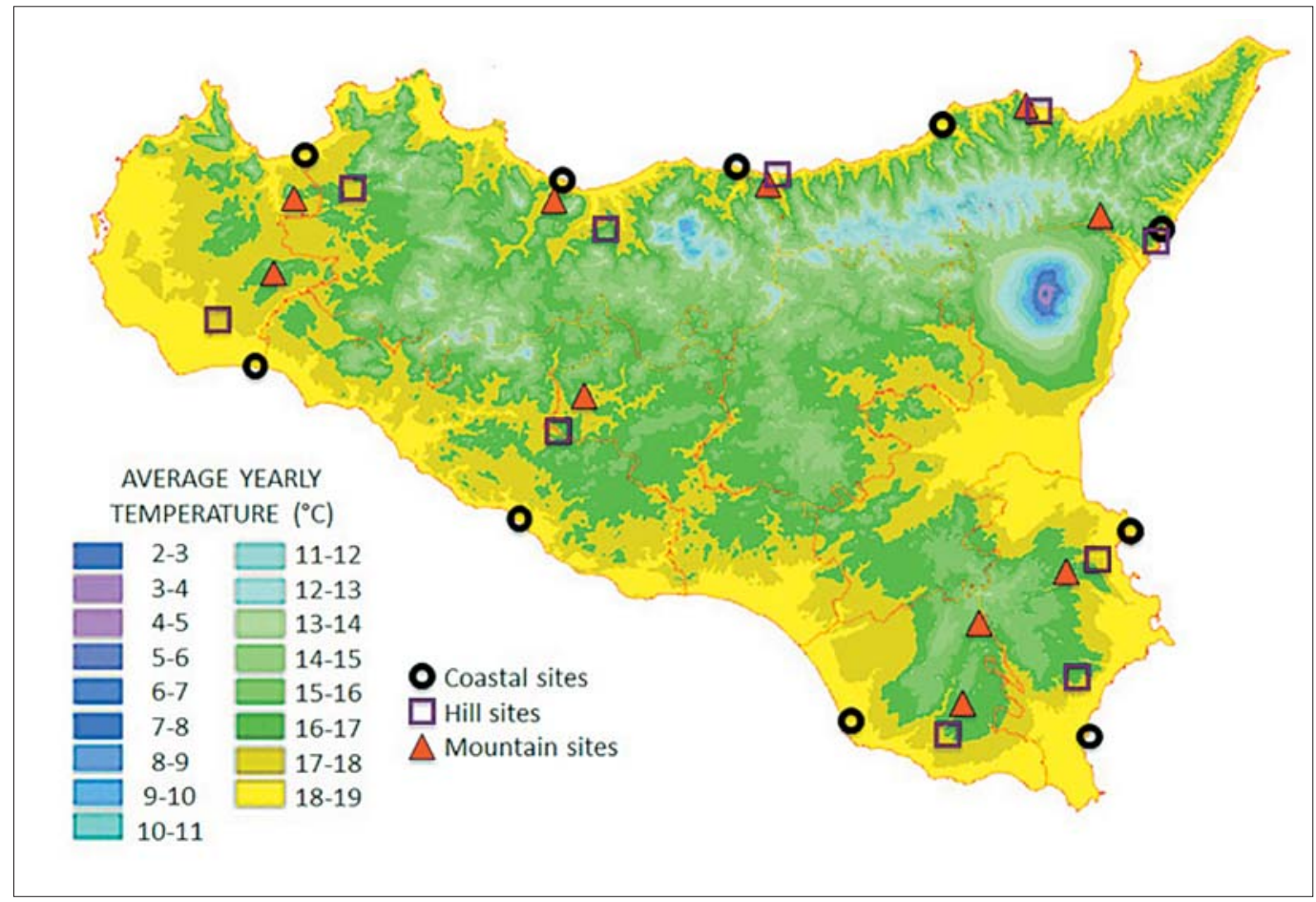

Fig. II - Average yearly air temperature in the period 1965-1994, based on data from the Sicilian Regional Hydrographic Service (after DRAGO, 2005), and localization of the 30 sampled sites.

At each sample date, in each site 20 leaves have been randomly collected from 5 trees, at man height in all four cardinal directions, reaching a total of 100 leaves. In this case the sampling time to collect 100 leaves has been set in 2 minutes. In order to have a larger set of data, if a total of 100 full mature lerps was not reached with the former sample, an additional sample was performed, collecting leaves bearing mature lerps directly from eucalyptus trees, recording the sampling time. In the laboratory the number of live $4^{\text {th }}-5^{\text {th }}$ instar nymphs, mummies and pierced mummies on each leaf has been counted. The final measure of the infestation was calculated as the number of live $4^{\text {th }}-5^{\text {th }}$ instar nymphs (including live mummies) collected per minute by one sampler in the field.

Regarding $P$. bliteus parasitization, all sampled leaves, after counting psyllid live instars, were put in glass jars, 
Table 1 - List of all sampling sites, their latitude, longitude, altitude and cumulative rainfall $(\mathrm{mm})$ recorded in 45 days preceding each sampling.

\begin{tabular}{|c|c|c|c|c|c|c|c|c|c|c|c|c|}
\hline \multirow{3}{*}{$\begin{array}{l}\text { Site } \\
\text { Nr. }\end{array}$} & \multirow{3}{*}{ Site name } & \multirow{3}{*}{$\begin{array}{l}\text { Latitude } \\
\text { N }\end{array}$} & \multirow{3}{*}{$\begin{array}{l}\text { Longitude } \\
\text { E }\end{array}$} & \multirow{3}{*}{$\begin{array}{l}\text { Group of } \\
\text { sites }\end{array}$} & \multirow{3}{*}{$\begin{array}{l}\text { Altitude } \\
\text { (m a.s.l.) }\end{array}$} & \multicolumn{7}{|c|}{ Rainfall of 45 days preceding the sampling } \\
\hline & & & & & & \multicolumn{2}{|c|}{$\begin{array}{c}\text { Spring } \\
\text { samples }\end{array}$} & \multicolumn{2}{|c|}{$\begin{array}{l}\text { Summer } \\
\text { samples }\end{array}$} & \multicolumn{2}{|c|}{$\begin{array}{l}\text { Autumn } \\
\text { samples }\end{array}$} & \multirow{2}{*}{$\begin{array}{c}\text { Winter sample } \\
\text { th }\end{array}$} \\
\hline & & & & & & $1 \mathrm{st}$ & 2nd & $3 \mathrm{rd}$ & 4th & 5 th & 6th & \\
\hline 1 & Augusta & $37^{\circ} 14^{\prime} 36.35^{\prime \prime}$ & $15^{\circ} 12^{\prime} 16.20^{\prime \prime}$ & Coast & 3 & 111 & 13 & 0 & 48 & 19 & 139 & 31 \\
\hline 2 & Vendicari & $36^{\circ} 48^{\prime} 15.70^{\prime \prime}$ & $15^{\circ} 05^{\prime} 34.10^{\prime \prime}$ & Coast & 5 & 61 & 2 & 1 & 0 & 22 & 101 & 75 \\
\hline 3 & Selinunte & $37^{\circ} 35^{\prime} 11.26^{\prime \prime}$ & $12^{\circ} 51^{\prime} 42.04^{\prime \prime}$ & Coast & 11 & 55 & 18 & 5 & 7 & 115 & 194 & 125 \\
\hline 4 & Randello & $36^{\circ} 50^{\prime} 25.00^{\prime \prime}$ & $14^{\circ} 27^{\prime} 38.80^{\prime \prime}$ & Coast & 15 & 113 & 3 & 0 & 0 & 119 & 137 & 74 \\
\hline 5 & $\begin{array}{l}\text { Rocca di } \\
\text { Caprileone }\end{array}$ & $38^{\circ} 06^{\prime} 40.30^{\prime \prime}$ & $14^{\circ} 42^{\prime} 33.46^{\prime \prime}$ & Coast & 16 & 95 & 84 & 0 & 14 & 69 & 151 & 181 \\
\hline 6 & San Leone & $37^{\circ} 16^{\prime} 08.92^{\prime \prime}$ & $13^{\circ} 34^{\prime} 38.10^{\prime \prime}$ & Coast & 17 & 82 & 5 & 0 & 15 & 59 & 166 & 81 \\
\hline 7 & $\begin{array}{l}\text { Termini } \\
\text { Imerese }\end{array}$ & $37^{\circ} 59^{\prime} 19.10^{\prime \prime}$ & $13^{\circ} 41^{\prime} 11.56^{\prime \prime}$ & Coast & 29 & 50 & 16 & 1 & 24 & 49 & 151 & 169 \\
\hline 8 & Letojanni & $37^{\circ} 52^{\prime} 55.25^{\prime \prime}$ & $15^{\circ} 18^{\prime} 09.55^{\prime \prime}$ & Coast & 30 & 107 & 32 & 6 & 9 & 38 & 145 & 48 \\
\hline 9 & Pollina & $38^{\circ} 01^{\prime} 21.61^{\prime \prime}$ & $14^{\circ} 09^{\prime} 11.77^{\prime \prime}$ & Coast & 33 & 50 & 39 & 0 & 1 & 33 & 106 & 167 \\
\hline 10 & Balestrate & $38^{\circ} 02^{\prime} 25.80^{\prime \prime}$ & $12^{\circ} 59^{\prime} 20.35^{\prime \prime}$ & Coast & 52 & 104 & 28 & 6 & 12 & 81 & 159 & 262 \\
\hline 11 & Patti & $38^{\circ} 08^{\prime} 47.34^{\prime \prime}$ & $14^{\circ} 57^{\prime} 43.28^{\prime \prime}$ & Hill & 101 & 69 & 38 & 0 & 6 & 46 & 84 & 236 \\
\hline 12 & Tusa bassa & $38^{\circ} 00^{\prime} 08.56^{\prime \prime}$ & $14^{\circ} 15^{\prime} 49.60^{\prime \prime}$ & Hill & 125 & 40 & 25 & 0 & 21 & 30 & 111 & 162 \\
\hline 13 & Lago Trinità & $37^{\circ} 41^{\prime} 08.33^{\prime \prime}$ & $12^{\circ} 45^{\prime} 36.52^{\prime \prime}$ & Hill & 168 & 79 & 27 & 4 & 13 & 90 & 202 & 169 \\
\hline 14 & Partinico & $37^{\circ} 58^{\prime} 16.39^{\prime \prime}$ & $13^{\circ} 07^{\prime} 04.59^{\prime \prime}$ & Hill & 195 & 95 & 39 & 4 & 21 & 81 & 168 & 223 \\
\hline 15 & Scicli & $36^{\circ} 48^{\prime} 45.00^{\prime \prime}$ & $14^{\circ} 42^{\prime} 57.00^{\prime \prime}$ & Hill & 200 & 142 & 1 & 0 & 6 & 92 & 131 & 104 \\
\hline 16 & Grotte & $37^{\circ} 27^{\prime} 22.77^{\prime \prime}$ & $13^{\circ} 40^{\prime} 43.54^{\prime \prime}$ & Hill & 242 & 83 & 17 & 2 & 15 & 146 & 216 & 131 \\
\hline 17 & Taormina & $37^{\circ} 51^{\prime} 42.00^{\prime \prime}$ & $15^{\circ} 17^{\prime} 01.10^{\prime \prime}$ & Hill & 250 & & & & No c & tic d & & \\
\hline 18 & Noto & $36^{\circ} 55^{\prime} 55.00^{\prime \prime}$ & $15^{\circ} 03^{\prime} 32.90^{\prime \prime}$ & Hill & 320 & 155 & 12 & 0 & 6 & 52 & 130 & 104 \\
\hline 19 & Melilli & $37^{\circ} 10^{\prime} 49.60^{\prime \prime}$ & $15^{\circ} 06^{\prime} 49.60^{\prime \prime}$ & Hill & 350 & 140 & 7 & 0 & 3 & 45 & 124 & 106 \\
\hline 20 & Cerda & $37^{\circ} 53^{\prime} 13.63^{\prime \prime}$ & $13^{\circ} 48^{\prime} 09.95^{\prime \prime}$ & Hill & 356 & 57 & 27 & 2 & 19 & 53 & 212 & 227 \\
\hline 21 & Caccamo & $37^{\circ} 57^{\prime} 02.70^{\prime \prime}$ & $13^{\circ} 40^{\prime} 10.22^{\prime \prime}$ & Mountain & 418 & & & & No c & tic $d$ & & \\
\hline 22 & $\begin{array}{l}\text { Francavilla } \\
\text { di Sicilia }\end{array}$ & $37^{\circ} 54^{\prime} 36.65^{\prime \prime}$ & $15^{\circ} 07^{\prime} 42.60^{\prime \prime}$ & Mountain & 425 & 178 & 92 & 0 & 12 & 53 & 122 & 131 \\
\hline 23 & Alcamo & $37^{\circ} 56^{\prime} 45.46^{\prime \prime}$ & $12^{\circ} 57^{\prime} 42.83^{\prime \prime}$ & Mountain & 439 & 93 & 54 & 2 & 14 & 92 & 176 & 234 \\
\hline 24 & Sortino & $37^{\circ} 09^{\prime} 35.80^{\prime \prime}$ & $15^{\circ} 01^{\prime} 57.70^{\prime \prime}$ & Mountain & 450 & & & & No c & tic $d$ & & \\
\hline 25 & Modica & $36^{\circ} 52^{\prime} 38.70^{\prime \prime}$ & $14^{\circ} 45^{\prime} 12.70^{\prime \prime}$ & Mountain & 460 & & & & No $\mathrm{c}$ & tic $d$ & & \\
\hline 26 & Sorrentini & $38^{\circ} 09^{\prime} 05.36^{\prime \prime}$ & $14^{\circ} 56^{\prime} 20.77^{\prime \prime}$ & Mountain & 478 & 74 & 64 & 0 & 16 & 78 & 176 & 334 \\
\hline 27 & Sutera & $37^{\circ} 31^{\prime} 49.11^{\prime \prime}$ & $13^{\circ} 44^{\prime} 42.34^{\prime \prime}$ & Mountain & 501 & 135 & 30 & 2 & 11 & 47 & 116 & 147 \\
\hline 28 & S. Ninfa & $37^{\circ} 47^{\prime} 05.12^{\prime \prime}$ & $12^{\circ} 54^{\prime} 38.63^{\prime \prime}$ & Mountain & 508 & 103 & 49 & 6 & 8 & 71 & 143 & 173 \\
\hline 29 & Giarratana & $37^{\circ} 02^{\prime} 53.50^{\prime \prime}$ & $14^{\circ} 47^{\prime} 58.00^{\prime \prime}$ & Mountain & 520 & 309 & 13 & 0 & 38 & 83 & 76 & 105 \\
\hline 30 & Tusa & $37^{\circ} 58^{\prime} 58.03^{\prime \prime}$ & $14^{\circ} 14^{\prime} 20.21^{\prime \prime}$ & Mountain & 542 & 63 & 42 & 0 & 27 & 16 & 114 & 179 \\
\hline \multicolumn{5}{|c|}{ Average coastal sites } & 21 & 83 & 24 & 2 & 13 & 60 & 145 & 121 \\
\hline \multicolumn{5}{|c|}{ Average hill sites } & 231 & 96 & 22 & 1 & 12 & 71 & 153 & 162 \\
\hline \multicolumn{5}{|c|}{ Average mountain sites } & 474 & 136 & 49 & 1 & 18 & 63 & 132 & 186 \\
\hline
\end{tabular}

topped with a cotton cloth, to avoid excess of moisture, and maintained at room temperature for at least 15 days to allow the emergence of both adults of the psyllid and the parasitoid. Parasitism rate was calculated as ratio between emerged parasitoids and all emerged adults (parasitoids + psyllids).

The climatic data of each site refer to the ones deriving from the closest available fitting station of the Sicilian Agrometeorological Information Service (SIAS) of the Sicilian Region that kindly provided the following weather recordings: rainfall (total amount, number of events, intensi- ty), relative humidity (daily percentage of $\mathrm{RH}>80 \%$ and of $\mathrm{RH}<40 \%$ ), air temperature (daily maximum, minimum and average). Rainfall intensity rates refer to the classification by the World Meteorological Organization (WMO, 2014) for precipitation in the form of liquid water drops that have diameters greater than $0.5 \mathrm{~mm}$ :

- light rain, $<0.41 \mathrm{~mm} / 10 \mathrm{~min}$;

- moderate rain, 0.41-1.6 mm/10 min;

- heavy rain, $>1.6 \mathrm{~mm} / 10 \mathrm{~min}$.

These daily data have been grouped and referred to the 45 days before each sampling date. Climatic data were not 
available for four out of thirty sampling sites (one hill site and three mountain sites), because no SIAS station fits with them (Tabb. 1-2).

\section{STATISTICAL ANALYSIS}

Data were analysed using the General Linear Model, in which the response variable is " $y$ " and the input variables are categorical and metric.

The first analysis regards $G$. brimblecombei infestation expressed as number of live $4^{\text {th }}-5^{\text {th }}$ nymphs collected per minute by one sampler (Inf/min). In order to apply the most common parametric statistics, the assumption of normality has to be satisfied. The original set of data was far from this distribution, but a simple transformation has been able to normalize data, $\mathrm{y}=\log (1+\mathrm{Inf} / \mathrm{min})$.

Input variables, categorical and metric:

- Sampling period, 1 (18-28 Apr. 2012), 2 (30 May-6 Jun. 2012), 3 (12-24 Jul. 2012), 4 (27 Aug.-6 Sep. 2012), 5 (11-18 Oct. 2012), 6 (27 Nov.-6 Dec. 2012), 7 (1-19 Feb. 2013).

- Site (see Tab. 1).

- Altitude, this metric variable has been used in alternative to Site.
- Parasitization (calculated as above described).

- Parasitization at the previous sampling.

- Light rain events (n) $<0.41 \mathrm{~mm} / 10 \mathrm{~min}$, recorded in 45 days preceding the sampling.

- Moderate rain events (n) $0.41-1.6 \mathrm{~mm} / 10 \mathrm{~min}$, recorded in 45 days preceding the sampling.

- Heavy rain events $(\mathrm{n})>1.6 \mathrm{~mm} / 10 \mathrm{~min}$, recorded in 45 days preceding the sampling.

- Total light rain $(\mathrm{mm})<0.41 \mathrm{~mm} / 10 \mathrm{~min}$, recorded in 45 days preceding the sampling.

- Total moderate rain $(\mathrm{mm}) 0.41-1.6 \mathrm{~mm} / 10 \mathrm{~min}$, recorded in 45 days preceding the sampling.

- Total heavy rain $(\mathrm{mm})>1.6 \mathrm{~mm} / 10 \mathrm{~min}$, recorded in 45 days preceding the sampling.

- Total rainfall $(\mathrm{mm})$, recorded in 45 days preceding the sampling.

- Average maximum temperature of 45 days preceding the sampling.

- Average temperature of 45 days preceding the sampling.

- Average minimum temperature of 45 days preceding the sampling.

- Percentage of daily hours with Relative Humidity $>80 \%$, recorded in 45 days preceding the sampling.

Table 2 - Average air temperature $\left({ }^{\circ} \mathrm{C}\right)$ recorded in 45 days preceding each sampling.

\begin{tabular}{|c|c|c|c|c|c|c|c|c|c|}
\hline \multirow{2}{*}{$\begin{array}{c}\text { Site } \\
\text { number }\end{array}$} & \multirow{2}{*}{ Site name } & \multicolumn{2}{|c|}{ Spring samples } & \multicolumn{2}{|c|}{ Summer samples } & \multicolumn{2}{|c|}{ Autumn samples } & \multirow{2}{*}{$\begin{array}{c}\text { Winter sample } \\
\text { 7th }\end{array}$} & \multirow{2}{*}{$\begin{array}{l}\text { Average 1st-7th } \\
\text { samples }\end{array}$} \\
\hline & & 1 st & 2nd & 3rd & 4th & 5th & 6th & & \\
\hline 1 & Augusta & 12.7 & 17.1 & 25.5 & 26.7 & 23.5 & 17.9 & 10.5 & 19.1 \\
\hline 2 & Vendicari & 14.0 & 17.9 & 24.5 & 27.4 & 24.7 & 19.2 & 12.4 & 20.0 \\
\hline 3 & Selinunte & 13.0 & 17.3 & 25.2 & 26.1 & 21.7 & 17.7 & 11.3 & 18.9 \\
\hline 4 & Randello & 15.2 & 18.1 & 24.9 & 27.7 & 24.0 & 18.6 & 11.6 & 20.0 \\
\hline 5 & Rocca di Caprileone & 14.7 & 17.3 & 25.0 & 26.8 & 24.4 & 18.9 & 11.6 & 19.8 \\
\hline 6 & San Leone & 13.4 & 17.3 & 24.6 & 26.0 & 22.9 & 18.3 & 11.5 & 19.2 \\
\hline 7 & Termini Imerese & 14.2 & 18.2 & 24.5 & 25.4 & 22.7 & 14.5 & 10.4 & 18.6 \\
\hline 8 & Letojanni & 12.9 & 16.4 & 23.2 & 26.4 & 22.8 & 17.7 & 11.6 & 18.7 \\
\hline 9 & Pollina & 14.2 & 16.7 & 24.4 & 26.0 & 23.2 & 16.7 & 10.4 & 18.8 \\
\hline 10 & Balestrate & 14.2 & 18.0 & 25.1 & 26.3 & 23.0 & 17.1 & 11.0 & 19.2 \\
\hline 11 & Patti & 13.4 & 16.1 & 24.0 & 25.6 & 23.1 & 16.2 & 9.9 & 18.3 \\
\hline 12 & Tusa bassa & 14.8 & 16.9 & 25.0 & 26.5 & 23.7 & 17.0 & 10.3 & 19.2 \\
\hline 13 & Lago Trinità & 12.8 & 17.2 & 25.6 & 26.4 & 21.9 & 16.9 & 9.9 & 18.7 \\
\hline 14 & Partinico & 13.4 & 17.5 & 24.2 & 25.1 & 21.9 & 15.2 & 9.7 & 18.2 \\
\hline 15 & Scicli & 13.2 & 17.1 & 25.2 & 27.7 & 23.0 & 18.1 & 10.4 & 19.2 \\
\hline 16 & Grotte & 11.7 & 18.2 & 27.4 & 27.9 & 22.7 & 16.2 & 9.0 & 19.0 \\
\hline 18 & Noto & 12.4 & 17.1 & 26.5 & 27.7 & 23.5 & 18.1 & 10.2 & 19.4 \\
\hline 19 & Melilli & 12.4 & 17.1 & 25.2 & 27.7 & 23.0 & 18.1 & 10.6 & 19.2 \\
\hline 20 & Cerda & 13.1 & 18.0 & 24.2 & 25.2 & 22.4 & 13.7 & 9.4 & 18.0 \\
\hline 22 & Francavilla di Sicilia & 12.1 & 15.9 & 24.0 & 26.9 & 22.4 & 13.9 & 9.4 & 17.8 \\
\hline 23 & Alcamo & 11.3 & 15.3 & 24.7 & 24.8 & 20.5 & 13.2 & 7.6 & 16.8 \\
\hline 26 & Sorrentini & 13.9 & 15.9 & 24.6 & 25.9 & 22.6 & 15.4 & 9.1 & 18.2 \\
\hline 27 & Sutera & 10.6 & 15.1 & 24.4 & 24.9 & 20.0 & 14.6 & 7.4 & 16.7 \\
\hline 28 & S. Ninfa & 11.9 & 16.0 & 25.7 & 26.0 & 21.7 & 16.3 & 8.8 & 18.1 \\
\hline 29 & Giarratana & 11.7 & 15.4 & 24.2 & 26.7 & 21.6 & 15.1 & 8.0 & 17.5 \\
\hline 30 & Tusa & 13.5 & 15.5 & 24.0 & 25.5 & 22.4 & 15.9 & 8.6 & 17.9 \\
\hline \multicolumn{2}{|c|}{ Average coastal sites } & 13.9 & 17.4 & 24.7 & 26.5 & 23.3 & 17.6 & 11.2 & 19.2 \\
\hline \multicolumn{2}{|c|}{ Average hill sites } & 13.0 & 17.3 & 25.3 & 26.7 & 22.8 & 16.6 & 9.9 & 18.8 \\
\hline \multicolumn{2}{|c|}{ Average mountain sites } & 12.2 & 15.6 & 24.5 & 25.8 & 21.6 & 14.9 & 8.4 & 17.6 \\
\hline
\end{tabular}


- Percentage of daily hours with Relative Humidity $<40 \%$, recorded in 45 days preceding the sampling.

Output variable:

$\mathrm{y}=\log (1+\operatorname{Inf} / \mathrm{min})$

In order to single out factors influencing $P$. bliteus parasitization, all variables have been taken into account, including the infestation level (this time used as input variable) and the lagged infestation level referred to the previous period. Input variables, categorical and metric:

- Sampling period, 1 (18-28 Apr. 2012), 2 (30 May-6 Jun. 2012), 3 (12-24 Jul. 2012), 4 (27Aug.-6 Sep. 2012), 5 (1118 Oct. 2012), 6 (27 Nov.-6 Dec. 2012), 7 (1-19 Feb. 2013).

- Site (see Tab. 1).

- Altitude, this metric variable has been used in alternative to Site.

- Infestation $=\log (1+\operatorname{Inf} / \mathrm{min})$.

- Infestation of the previous sampling.

- Light rain events (n) $<0.41 \mathrm{~mm} / 10 \mathrm{~min}$, recorded in 45 days preceding the sampling.

- Moderate rain events (n) $0.41-1.6 \mathrm{~mm} / 10 \mathrm{~min}$, recorded in 45 days preceding the sampling.

- Heavy rain events (n) $>1.6 \mathrm{~mm} / 10 \mathrm{~min}$, recorded in 45 days preceding the sampling.

- Total light rain $(\mathrm{mm})<0.41 \mathrm{~mm} / 10 \mathrm{~min}$, recorded in 45 days preceding the sampling.

- Total moderate rain (mm) $0.41-1.6 \mathrm{~mm} / 10 \mathrm{~min}$, recorded in 45 days preceding the sampling.

- Total heavy rain $(\mathrm{mm})>1.6 \mathrm{~mm} / 10 \mathrm{~min}$, recorded in 45 days preceding the sampling.

- Total rainfall $(\mathrm{mm})$, recorded in 45 days preceding the sampling.

- Average maximum temperature of 45 days preceding the sampling.

- Average temperature of 45 days preceding the sampling.

- Average minimum temperature of 45 days preceding the sampling.
- Percentage of daily hours with Relative Humidity $>80 \%$, recorded in 45 days preceding the sampling.

- Percentage of daily hours with Relative Humidity $<40 \%$, recorded in 45 days preceding the sampling.

Output variable: $\mathrm{y}=$ Parasitization

In order to single out the best model, a progressive elimination of variables has been performed, dropping out variables one by one as they show the lowest significance level (higher P-value). In this way we can obtain the model showing the highest global significance with the lowest number of variables.

For what concerns weather conditions, as the variables are closely correlated with each other, it is reasonable that only a few of them have been selected in the final model.

As regards the influence of altitude, an alternative model has been tested; here only the altitude of the site is taken into account instead of the different sites. This model is more parsimonious, because it uses just one degree of freedom instead of 25 .

\section{RESULTS}

Rainfall and average temperature recorded in the sampling period are shown in Fig. III and Tabb. 1, 2; these records are close to those recorded in 1965-1994 (DRAGO, 2005).

P. bliteus was the only parasitoid emerged from G. brimblecombei; it has been recovered in all 30 sampled sites, confirming data from our preliminary survey performed in winter 2011-12 and stating that the parasitoid is widespread all over Sicily.

G. brimblecombei infestation and P. bliteus parasitization levels recorded in all seasonal samplings are shown in Figs IV-VII, while the average levels recorded in each altitudinal

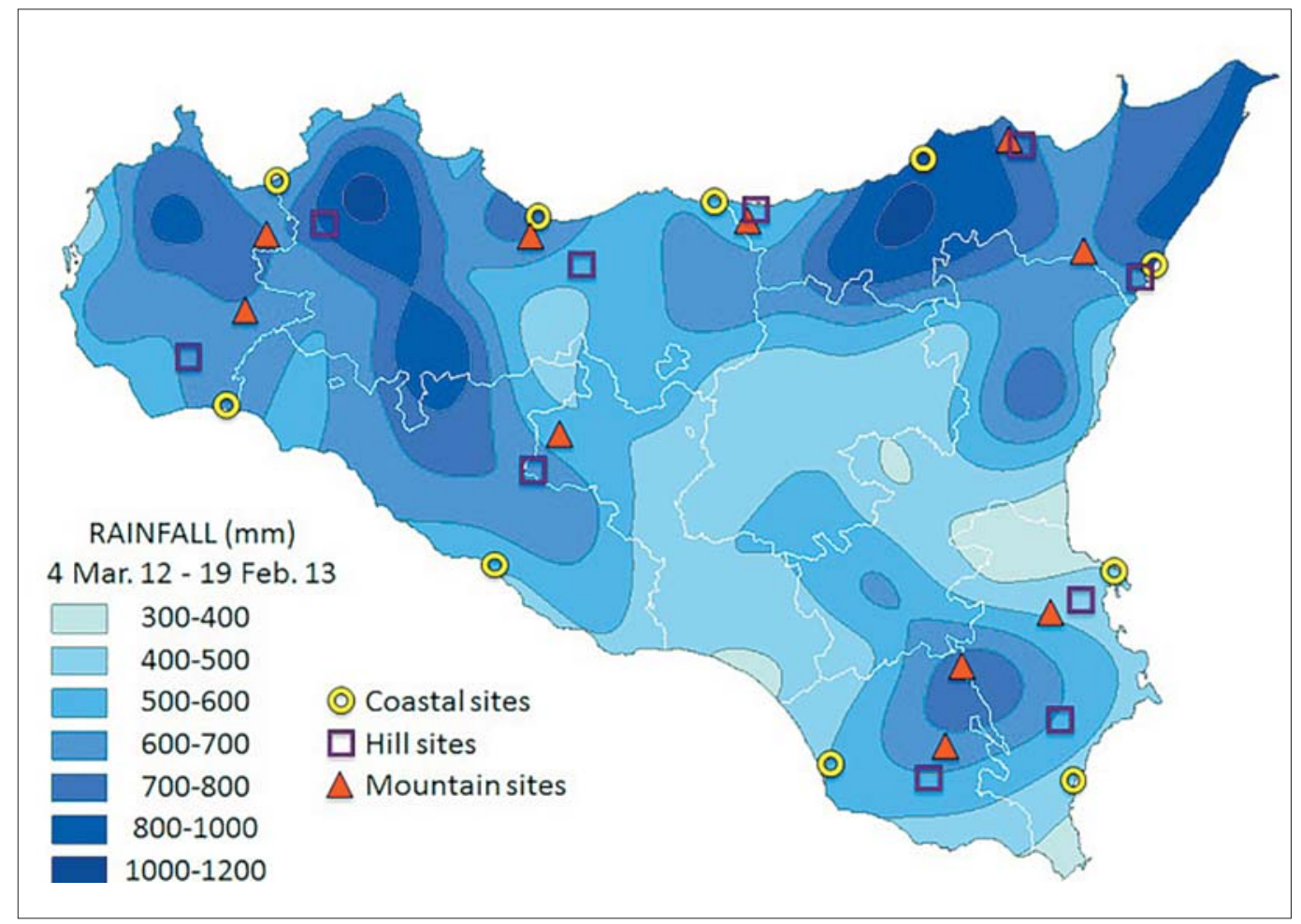

Fig. III - Sampled sites and map of rainfall recorded in Sicily during the sampling period, 4 Mar. 2012-19 Feb. 2013 (map kindly drawn by Luigi Pasotti using all daily data coming from SIAS stations). 

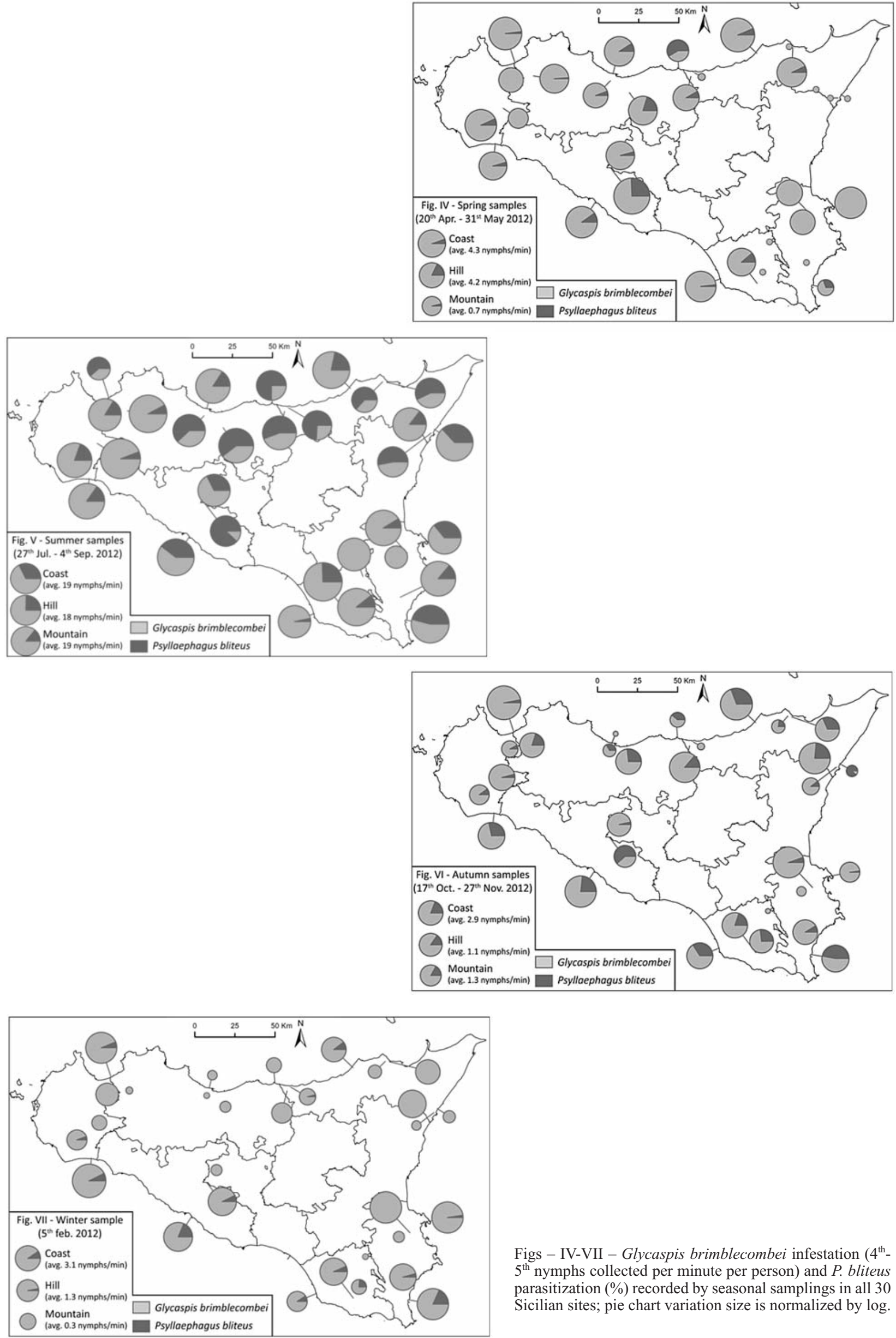

Figs - IV-VII - Glycaspis brimblecombei infestation $\left(4^{\text {th }}\right.$ $5^{\text {th }}$ nymphs collected per minute per person) and P. bliteus parasitization (\%) recorded by seasonal samplings in all 30 Sicilian sites; pie chart variation size is normalized by log. 
group of sites is shown in Fig. VIII. In spite of some differences detectable in these figures, infestation and parasitization levels recorded at three different ranges of altitude resulted not statistically different; as shown in Figs IV-VII the variability of both infestation and parasitization levels is very high.

In all three altitudinal ranges infestation by $G$. brimblecombei reached a clear peak during the first summer sampling performed in July (Fig. VIII, 1), while the peak of parasitization due to $P$. bliteus was a little delayed maintaining high percentages also in the second summer sampling and the first one of autumn (Fig. VIII, 2).

The results of statistical analysis related to the infestation, measured as number of live $4^{\text {th }}-5^{\text {th }}$ nymphs collected per minute per person, are reported in the final model (Tab. 3).

As already described in materials and methods, Tab. 3 shows the input variables resulted as the most significant ones, obtaining the model having the highest global significance with the lowest number of variables.

The variable with the highest impact on infestation levels is $P$. bliteus parasitization (see Adjusted MS and F in Tab. 3). Although theoretical model contemplates that the present infestation depends on the previous parasitization, at unknown lag, evidently such lag is closer to the present date of sampling than to the previous sampling, which is around 45 days before the present date. This could be the reason why between the two covariate, parasitization and parasitization at the previous sampling period, the first one results significant, while the second one can be eliminated. Obviously, the parasitization enters the model with a negative slope (see coefficient in Tab. 3) that is an increment of the parasitization lowers the infestation.

As the variables of weather conditions are closely corre- lated one to each other, the average percentage of daily hours with $\mathrm{RH}>80 \%$ was selected in the final model as the most significant one; for temperature, the chosen one is the average maximum temperature of the 45 preceding days, while rainfall is not present among the most significant variables, probably because it is linked to the relative humidity. Both of selected climatic variables $(\mathrm{RH}>80 \%$ and average maximum temperature) enter the model with a positive slope (see coefficient in Tab. 3).

Beside the weather conditions, also the sampling period is significant; the site, although significant, has lower impact (Tab. 3).

An alternative model has been tested; there, in place of the different sites, only the altitude of the site was taken into account. This model is more parsimonious because it uses just one degree of freedom instead of 25; unfortunately, it explains a significantly smaller part of variance; this means that the altitude is an important factor, although many other local factors, typical of the site, are also influent, but the variability of the sites is very high.

Also in the statistical analysis regarding the factors influencing the parasitization, the lagged variable (infestation of the previous period) has resulted to be not significant, probably due to the same reasons expressed in the previous analysis regarding the infestation. The infestation has a negative impact, and this could be considered reasonable, because when there is an outbreak of infestation, the parasitization has a delay in the rise. In Tab. 4, the sampling period is the main factor influencing the parasitization, followed by the infestation level (with negative influence, as already written) and the percentage of daily hours with relative humidity $>80 \%$ (positively influencing). The altitude is an important factor too, but single sites explain significantly

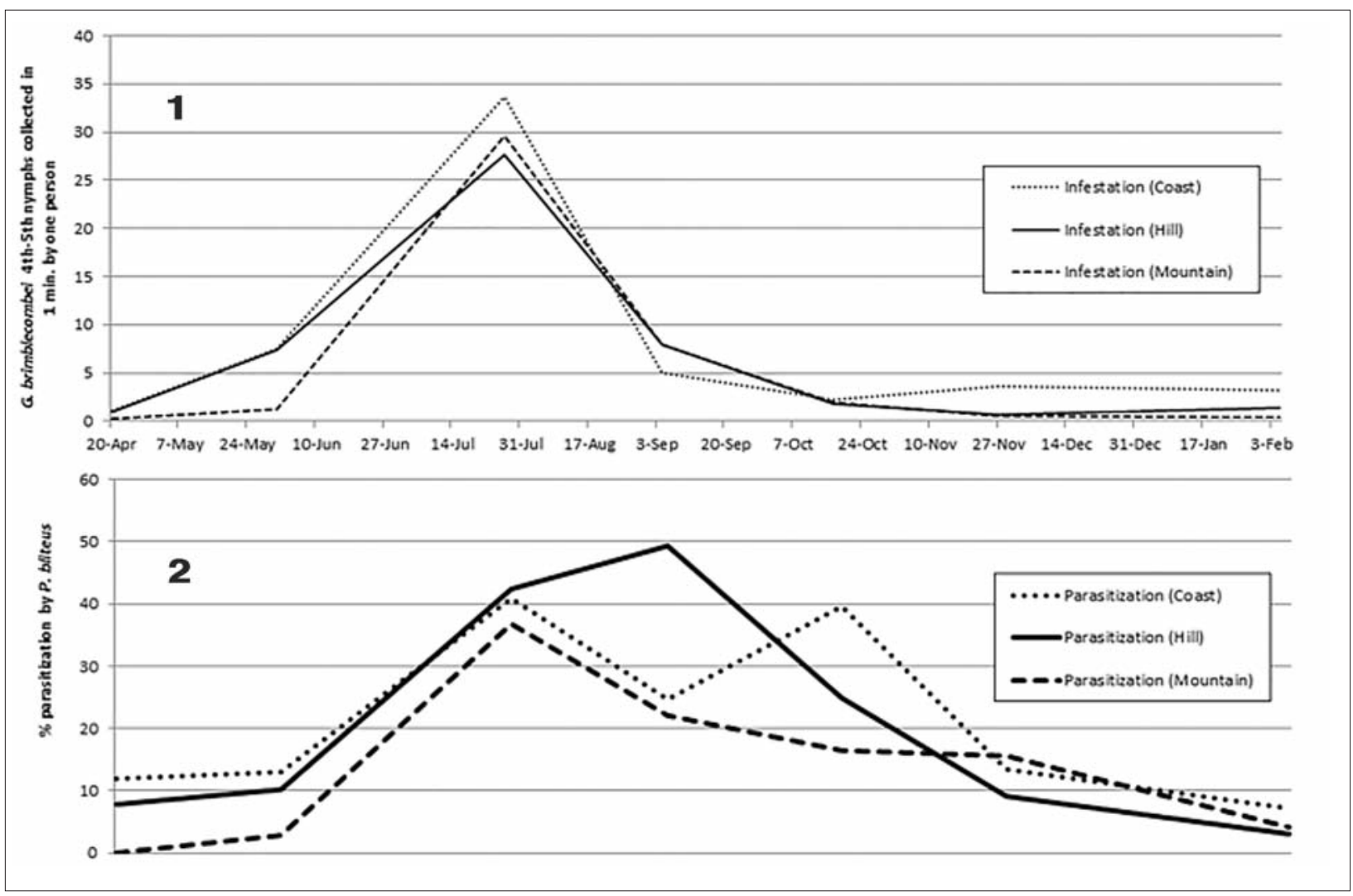

Fig. VIII - Trend of average infestation level of G. brimblecombei (1) and percentage of parasitization by P. bliteus (2) recorded in all groups of sites (Coast, Hill and Mountain). 
Table 3 - Analysis of Variance for G. brimblecombei infestation, $\log (1+$ Infestation/min), using Adjusted SS for Tests.

\begin{tabular}{|c|c|c|c|c|c|c|c|}
\hline Source & DF & Seq SS & Adj SS & Adj MS & $\mathbf{F}$ & $\mathbf{P}$ & $\begin{array}{c}\text { Coefficient } \\
\text { (metric } \\
\text { variable) }\end{array}$ \\
\hline P. bliteus parasitization & 1 & 0.051 & 8.940 & 8.940 & 28.21 & 0.000 & -1.317 \\
\hline Percentage of daily hours with Relative Humidity $>80 \%$ & 1 & 2.544 & 4.121 & 4.121 & 13.01 & 0.000 & 0.020 \\
\hline Average maximum temperature & 1 & 9.197 & 2.944 & 2.944 & 9.29 & 0.003 & 0.144 \\
\hline Sampling period & 6 & 17.143 & 17.965 & 2.994 & 9.45 & 0.000 & \\
\hline Site & 25 & 37.090 & 37.090 & 2.994 & 4.68 & 0.000 & \\
\hline Error & 118 & 37.390 & 37.390 & 0.317 & & & \\
\hline Total & 152 & 103.415 & & & & & \\
\hline $\mathrm{S}=0.562908, \mathrm{R}-\mathrm{Sq}=63.84 \%, \mathrm{R}-\mathrm{Sq}(\mathrm{adj})=53.43 \%$ & & & & & & & \\
\hline
\end{tabular}

Table 4 - Analysis of Variance for P. bliteus parasitization, using Adjusted SS for Tests.

\begin{tabular}{|c|c|c|c|c|c|c|c|}
\hline Source & DF & Seq SS & Adj SS & Adj MS & $\mathbf{F}$ & $\mathbf{P}$ & $\begin{array}{c}\text { Coefficient } \\
\text { (metric } \\
\text { variables) }\end{array}$ \\
\hline Sampling period & 6 & 7.370 & 9.396 & 1.566 & 44.32 & 0.000 & \\
\hline $\log (1+$ Infestation $/ \mathrm{min})$ & 1 & 0.009 & 0.952 & 0.952 & 26.95 & 0.000 & -0.138 \\
\hline $\begin{array}{l}\text { Percentage of daily hours with Relative Humidity } \\
>80 \%\end{array}$ & 1 & 1.170 & 0.561 & 0.561 & 15.88 & 0.000 & 0.007 \\
\hline Site & 25 & 6.387 & 6.387 & 0.255 & 7.23 & 0.000 & \\
\hline Error & 119 & 4.204 & 4.204 & 0.035 & & & \\
\hline Total & 152 & 19.140 & & & & & \\
\hline$S=0.187961, R-S q=78.04 \%, R-S q(a d j)=71.94 \%$ & & & & & & & \\
\hline
\end{tabular}

more; so that we can say - as previously seen - that there are local conditions that cannot be reduced to a simple altitudinal factor.

\section{DISCUSSION}

After the first record of $P$. bliteus in Sicily, its spread all over the region occurred in a short time, showing the high dispersal capacity. Similarly, Closterocerus chamaeleon (Girault), a parasitoid released in Sicily to control the eucalypt gall wasp Ophelimus maskelli (Ashmead) (Hymenoptera, Eulophidae) (RIzzo et al., 2015), rapidly spread through short and long distance dispersal mechanism, being widely distributed in the region after 18 months from its release in 2006 (CALECA et al., 2011b).

At present, Psyllaephagus bliteus is widespread in Sicily and has been recorded at all detected altitudes without statistically significant differences.

Mediterranean areas fits with the good development of Eucalyptus camaldulensis, Glycaspis brimblecombei and its specific parasitoid $P$. bliteus, differently from what recorded in the arid climatic areas of inner California, where E. camaldulensis and $P$. bliteus showed clear difficulties in their development (DAANE et al., 2012).

$P$. bliteus parasitization is the main factor negatively influencing (=lowering) G. brimblecombei infestation; this result, together with the accidental and contemporaneous introduction of the psyllid and its parasitoid (CALECA et al., 2011a), could explain the absence of high damage level on eucalypts in Sicily, confirming results achieved by MARGIOTTA et al. (2017) which state that $P$. bliteus parasitization causes a $64 \%$ reduction of the host population. In this context, it is to further investigate the influence that a strong attack of the invasive bronze bug Thaumastocoris peregrinus Carpintero \& Dellapé (Heteroptera, Thaumastocoridae) can have against both the host and the parasitoid (SUMA et al., 2014, 2018).

The most significant metric factors positively influencing G. brimblecombei infestation are daily hours above $80 \%$ of relative humidity and the average maximum temperature, obviously related to other, but less significant climatic factors.

Sampled sites with their particular characteristics are factors influencing infestation and parasitization more than their altitude; therefore local conditions of each site cannot be reduced to a simple altitudinal factor.

P. bliteus parasitization on G. brimblecombei showed to be influenced by the sampling period, as well as by the host infestation level (negatively) and by the percentage of daily hours of relative humidity $>80 \%$ (positively), recording the highest average levels in summer samplings.

The time interval of about 45 days between one sample and the next was not able to confirm that both G. brimble- 
combei infestation and $P$. bliteus parasitization were influenced by previous recorded levels as stated by MARGIOTTA et al. (2017), because current levels are likely affected by previous levels reached in a moment closer to current sampling than to the previous one.

\section{ACKNOWLEDGEMENTS}

This research was partially supported by the Sicilian Region Project "Studi ed indagini sulla presenza di avversità biotiche d'interesse forestale e sulle strategie di lotta" and by the project "Insects and globalization: sustainable control of exotic species in agroforestry ecosystems (GEISCA)", funded by the Italian Ministry for Education, University and Research (PRIN 2010/2011, project 2010CXXHJE 004). Climatic data have been kindly provided by the Sicilian Agrometeorological Information Service of the Sicilian Region (Regione Siciliana - SIAS - Servizio Informativo Agrometeorologico Siciliano). Dr. Luigi Pasotti (SIAS) drew the map on rainfall of the sampling period used to realize Fig. III.

\section{REFERENCES}

Baldini A., Carballo R., Telechea N., Porcile J., Alfenas A., 2006 - Plagas y enfermedades de Eucaliptos y Pinos en el Uruguay. - FAO y Ministerio de Ganaderia Agricoltura y Pesca, $167 \mathrm{pp}$.

BAMI R., 2011-Au secours de l'eucalyptus. - Le matin, 9 Juin 2011: 6.

Bella S., 2013 - New alien insect pests to Portugal on urban ornamental plants and additional data on recently introduced species. - Annales de la Société entomologique de France (N.S.), 49 (4): 374-382.

BELla S., 2014 - Invasive insect pests and their associated parasitoids on ornamental urban plants on Corfu island Phytoliriomyza jacarandae Steyskal and Spencer 1978 (Diptera, Agromyzidae) a new record in Greece. - Hellenic Plant Protection Journal, 7: 53-59.

BELLA S., RAPISARDA C., 2013 - First record from Greece of the invasive red gum lerp psyllid Glycaspis brimblecombei Moore (Hemiptera: Psyllidae) and its associated parasitoid Psyllaephagus bliteus Riek (Hymenoptera: Encyrtidae). - Redia, 96: 33-35.

BElla S., RAPISARDA C., 2014 - New findings in Italy of the recently introduced alien psyllid Macrohomotoma gladiata and additional distributional records of Acizzia jamatonica and Cacopsylla fulguralis (Hemiptera Psylloidea). - Redia, 97: 151-155.

BEN ATTIA S., RAPISARDA C., 2014 - First record of the red gum lerp psyllid, Glycaspis brimblecombei Moore (Hemiptera Psyllidae), in Tunisia. - Phytoparasitica, 42 : 535-539.

BerRY J.A., 2007 - Key to the New Zealand species of Psyllaephagus Ashmead (Hymenoptera: Encyrtidae) with descriptions of three new species and a new record of the psyllid hyperparasitoid Coccidoctonus psyllae Riek (Hymenoptera: Encyrtidae). - Australian Journal of Entomology, 46: 99-105.

Berti-Filho E., Costa V.A., Zuparko R.L., La Salle J., 2003 - Ocorrência de Psyllaephagus bliteus Riek (Hymenoptera: Encytidae) no Brasil. - Revista de Agricultura, Piracicaba, 78 (3): 304.

Bouvet J.P.R., HARRAND L., BURCKHARDT D., 2005 Primera cita de Blastopsylla occidentalis y Glycaspis brimblecombei (Hemiptera: Psyllidae) para la República
Argentina. - Revista Sociedad Entomológica Argentina, 64: 99-102.

Brennan E.B., Gill R.J., Hrusa G.F., Weinbaum S.A., 1999 - First record of Glycaspis brimblecombei (Moore) (Homoptera: Psyllidae) in North America: initial observations and predator associations of a potentially serious new pest of Eucalyptus in California. - Pan-Pacific Entomologist, 75: 55-57.

BurcKhardT D., LOZADA P.W., DiAz B.W., 2008 - First record of the red gum lerp psyllid Glycaspis brimblecombei (Hemiptera: Psylloidea) from Peru. - Bull. Soc. Entomol. Suisse, 81: 83-85.

Caleca V., Lo Verde G., Maltese M., 2011a - First record in Italy of Psyllaephagus bliteus Riek (Hymenoptera Encyrtidae) parasitoid of Glycaspis brimblecombei Moore (Hemiptera Psyllidae). - Naturalista siciliano, ser. IV, 35: 435-444.

Caleca V., Lo Verde G., Rizzo M.C., Rizzo R., 2011b Dispersal rate and parasitism by Closterocerus chamaeleon (Girault) after its release in Sicily to control Ophelimus maskelli (Ashmead) (Hymenoptera, Eulophidae). - Biological Control, 57: 66-73, doi: 10.1016/j.biocontrol.2010.12.006.

Cibrián T.D., IÑIgUeZ G., DAhlsten D.L., 2001 Conchuela del eucalipto Glycaspis brimblecombei Moore (Homoptera: Psylloidea; Spondylaspididae). Una nueva plaga del eucalipto introducida a Mexico. - Memorias del XXXVI Congreso Nacional de Entomologia. Santiago de Querétaro, Querétaro: pp. E-95.

Cocquempot C., Malausa J.C., Thaon M., Brancaccio L., 2012 - The Red Gum Lerp Psyllid (Glycaspis brimblecombei Moore) introduced on French eucalyptus trees (Hemiptera, Psyllidae). - Bulletin de la Société Entomologique de France, 117(3): 363-370.

DAANE K.M., Sime K.R., DAhlsten D.L., ANDREws J.W. JR., ZUPARKO R.L., 2005 - The biology of Psyllaephagus bliteus Riek (Hymenoptera: Encyrtidae), a parasitoid of the red gum lerp psyllid (Hemiptera: Psylloidea). - Biological Control, 32: 228-235. - doi: 10.1016/j.biocontrol.2004.09.015.

DaAne K.M., Sime K.R., PAINE T.D., 2012 - Climate and the effectiveness of Psyllaephagus bliteus as a parasitoid of the red gum lerp psyllid. - Biocontrol Science and Technology, 22: 1305-1320.

Dahlsten D.L., DaAne K.M., Paine T.D., Sime K.R., Lawson A.B., Rowney D.L., Roltsch W.J., ANDREws J.W. JR., KabaShima J.N., ShaW D.A., RobB K.L., Downer J.A., Geisel P.M., Chaney W.E., Ingels C.A., VARELA L.G., BIANCHI M.L., TAYLOR G., 2005 - Imported parasitoid helps control red gum lerp psyllid. - California Agriculture, 59: 229-234. doi: 10.3733/ca.v059n04.

DAhlsten D.L., Rowney D.L., RobB K.L., Downer J.A., Shaw D.A., Kabashima J.N., 2002 - Biological control of introduced psyllids on eucalyptus. - Proceedings of the 1st International Symposium on Biological Control of Arthropods, Honolulu, Hawaii, 14-18 January 2002, pp. 357 (Ed: Driesche, R.G. van) United States Department of Agriculture, Forest Service, Washington, USA.

De Queiroz D.L., Burckhardt D., Majer J., 2012 Integrated Pest Management of Eucalypt Psyllids (Insecta, Hemiptera, Psylloidea), Integrated Pest Management and Pest Control - Current and Future Tactics, Dr. Sonia Soloneski (Ed.), 668 pages.

Dhahri S., Ben JamaA M.L., Garcia A., Boavida C., BRANCO M., 2014 - Presence of Glycaspis brimblecombei and its Parasitoid Psyllaephagus bliteus in Tunisia and Portugal. - Silva Lusitana, 22 (1): 99-115. 
Drago A., 2005 - Atlante climatologico della Sicilia. Seconda Edizione. - Rivista Italiana di Agrometeorologia, 10 (2): 67-83.

EPPO (European and Mediterranean Plant Protection Organization), 2011 - Glycaspis brimblecombei occurs in Sardinia 2011/041. - EPPO Reporting Service 2011 (2): 12.

Ferreira-Filho P.J., WilcKen C.F., Lima A.C.V., NogueIRA de Sá L.A., Braga do Carmo J., Guerreiro J.C., Cola ZANUNCIO J., 2015 - Biological control of Glycaspis brimblecombei (Hemiptera: Aphalaridae) in eucalyptus plantations. - Phytoparasitica, 43 (2): 151-157.

Garonna A.P., SASSo R., LAUdOnia S., 2011 - Glycaspis brimblecombei (Hem.: Psyllidae), la psilla dal follicolo bianco ceroso, altra specie aliena dell'Eucalipto rosso in Italia. -Forest@, 18: 71-77.

GILL R.J., 1998 - New state record: Redgum lerp psyllid, Glycaspis brimblecombei. - California Plant Pest Dis. Report, 17: 7-8.

Halbert S.E., Gill R.J., Nisson J.N., 2001 - Two Eucalyptus psyllids new to Florida (Homoptera: Psyllidae). - Florida Department of Agriculture Entomology Circular, 407: 1-2.

Herting B., 1972 - Homoptera. A catalogue of parasites and predators of terrestrial arthropods. Section A. Host or Prey/Enemy. - Commonwealth Agricultural Bureaux, Slough, England, 2: 27.

Hollis D., 2004 - Australian Psylloidea: Jumping plant lice and lerps insects. - Australia Biological Resources Study, Canberra, Australia, XVI + 216 pp.

Hurtado A., Reina I., 2008 - Primera cita para Europa de Glycaspis brimblecombei Moore (Hemiptera: Psyllidae), una nueva plaga del eucalipto. - Bol. Soc. entomol. aragonesa, 43: 447-449.

IBNELAZYZ A, 2011 - Le Psylle d'Eucalyptus dans la Province d'El Kalaa des Sraghna. - Bulletin Phytosanitaire de l'ONSSA, 1 (1): 3-4.

Ide M.S., Munoz A.C., BeEche C.M., Mondaca E.J., JaQues R.L., Gonzalez P., Goycoolea P.C., 2006 Deteccion y control biologico de Glycaspis brimblecombei Moore (Hemiptera: Psyllidae). - Servicio Agrìcola y Ganadero, Division de Proteccion Agricola, Santiago, Chile, pp. 32.

JimÉnez G.E., 2013 - Presencia del Psílido del Eucalipto (Glycaspis brimblecombei Moore: Psyllidae) en El Salvador. - Bioma, 1(8): 45-49. http://www.academia.edu/ 4241323/Bioma Junio.

Karaca İ., KaYAHĀN A., ŞIMȘEK B., ÇELIKPENÇE Y., 2015 First record of Glycaspis brimblecombei Moore (Hemiptera: Aphalaridae), in Turkey. - Phytoparasitica, 43 (2): 171-175.

LAUDONIA S., GaRonNa A.P., 2010 - The red gum lerp psyllid, Glycaspis brimblecombei, a new exotic pest of Eucalyptus camaldulensis in Italy. - Bull. Insectol., 63: 233-236.

LaUdonia S., Margiotta M., Sasso R., 2014 - Seasonal occurrence and adaptation of the exotic Glycaspis brimblecombei Moore (Hemiptera: Aphalaridae) in Italy. Journal of Natural History, 48 (11-12): 675-689.

lo Verde G., Bella S., Caleca V., Rapisarda C., Sidoti A., 2011 - Presenza in Sicilia di Glycaspis brimblecombei Moore (Hemiptera Psyllidae) su Eucalyptus camaldulensis Dehnh. - Naturalista Siciliano, 4: 425-434.

MALUMPHY C., 2010. - First record of the red gum lerp psyllid, Glycaspis brimblecombei Moore (Hemiptera: Psyllidae), in the Canary Islands. - Entomologist's Monthly Magazine, 146 (1754-59): 148. http://www.pemberleybooks.com.
Malumphy C., Perovic T., Hrncic S., Radonjic S. RAICEVIC M., 2013 - First records of Acizzia jamatonica (Kuwayama) and Glycaspis brimblecombei Moore, (Hemiptera: Psyllidae, Aphalaridae) in Montenegro. Acta Entomologica Serbica, 18(1/2): 11-15. http://www.eds. org.rs/AES/Vol18/AES\%2018\%20-\%20Malumphy $\% 20$ et $\% 20$ al.pdf.

Margiotta M., Bella S., Buffa F., Caleca V., Floris I., Giorno V., Lo Verde G., Rapisarda C., Sasso R., Suma P., TORTORici F., LAUdonia S., 2017 - Modeling Environmental Influences in the Psyllaephagus bliteus (Hymenoptera: Encyrtidae) - Glycaspis brimblecombei (Hemiptera: Aphalaridae) Parasitoid-Host System. Journal of Economic Entomology, 110 (2): 491-501

Nagamine W.T., Heu R.A., 2001 - Red gum lerp psyllid Glycaspis brimblecombei Moore (Homoptera: Psyllidae). - New Pest Advisory, pp. 01-02.

Noyes, J.S., Hanson P., 1996 - Encyrtidae (Hymenoptera: Chalcidoidea) of Costa Rica: the genera and species associated with jumping plant-lice (Homoptera: Psylloidea) Bulletin of The Natural History Museum (Entomology Series), 65(2): 105-164.

OnORE G., Gara, R.L., 2007 - First record of Glycaspis brimblecombei (Hemiptera: Psyllidae) in Ecuador, biological notes and associated fauna. - Extended Abstracts of the 4th European Hemiptera Congress, Ivrea, Turin, Italia: 41-42.

Paine T.D., Dahlsten D.L., Millar J.G., Hoddle M.S., HANKS L.M., 2000 - UC scientists apply IPM techniques to new eucalyptus pests. - California Agriculture, 54: 8-13. - doi: 10.3733/ca.v054n06p8.

Pérez-Otero R., Borrajo P., Mansilla J.P., Ruiz, F., 2011 - Primeracita en España de Psyllaephagus bliteus Riek (Hymenoptera, Encyrtidae), parasitoide de Glyeaspis brimbleeombei Moore (Hemiptera, Psyllidae). - Bol. San. Veg. Plagas, 37 (1): 37-44.

Peris-Felipo F.J., Mancusi G., Turrisi G.F., JiménezPEYDRÓ R., 2011 - New corological and biological data of the Red Gum Lerp Psyllid, Glycaspis brimblecombei Moore, 1964 in Italy (Hemiptera, Psyllidae). Biodiversity Journal, 2 (1): 13-17.

PIBIRI M., 2011 - Il killer degli eucalpiti plana sull'Isola. L'unione Sarda, 27 gennaio, p. 33.

Plascencia-González A., Cibrián-Tovar D., LlanderalCÁzARes C., LóPEZ-PÉrez I., ArRiola-PADilla V., 2005 Biologia del parasitoide Psyllaephagus bliteus (Hymenoptera: Encyrtidae). - Revista Chapingo Serie Ciencias Forestales y del Ambiente, 11(1): 11-17.

Reguia K., Peris-Felipo F.J., 2013 - Glycaspis brimblecombei Moore, 1964 (Hemiptera Psyllidae) invasion and new records in the Mediterranean area. Biodiversity Journal, 4(4): 501-506.

RIEK E.F., 1962 - The Australian species of Psyllaephagus (Hymenoptera, Encyrtidae), parasities of psyllids (Homoptera). - Australian Journal of Zoology 10(4): 684757.

Rizzo M.C., Lo Verde G., Rizzo R., CALECA V., 2015 - Risk assessment of non-target effects of Closterocerus chamaeleon (Girault) parasitoid of the eucalypt gall maker Ophelimus maskelli (Ashmead) (Hymenoptera, Eulophidae). - Phytoparasitica, 43 (3): 407-415. DOI: $10.1007 / \mathrm{s} 12600-015-0472-3$

Rodas C.A., Serna R., Hurley B.P., Bolanos M.D., Granados G.M., WingFIELD M.J., 2014 - Three new and important insect pests recorded for the first time in Colombian plantations. - Southern Forests: a Journal of Forest Science, 76(4): 245-252. 
Rosales C.J., Lobosque O., Carvalho P., Bermudez L., Acosta C., 2008 - Glycaspis brimblecombei Moore (Hemiptera: Psyllidae). "Red Gum Lerp". Nueva plaga forestal en Venezuela. - Entomotropica, 35: 103-104.

Sandoval A., Rothmann S., 2003 - Detección del psílido de los eucaliptos rojos, Glycaspis brimblecombei Moore (Hemiptera: Psyllidae) en Chile. In: $24^{\circ}$ Congreso Nacional de Entomología, Resúmenes. (http://www.udec.cl/insectos/resúmenes.html).

Santana D.L.Q., Mendezes A.O., Silva H.D., Bellote A.F.J., FAVERO R.M., 2003 - O Psilideo de concha (Glycaspis brimblecombei) em eucalipto. - Comunicaçao Técnica, p. 105.

Sookar P., Seewooruthun S.I., Ramkhelawon D., 2013 The redgum lerp psyllid, Glycaspis brimblecombei, a new pest of Eucalyptus $s p$. in Mauritius. - AMAS, Food and Agricultural Research Council, Réduit, Mauritius: 327332.

Suma P., Nucifora S., Bella S., 2014 - New distribution record of the invasive bronze bug Thaumastocoris peregri- nus Carpintero and Dellapé (Heteroptera, Thaumastocoridae) in Italy. - Bulletin OEPP/EPPO Bulletin, 44 (2): 179-182.

Suma P., Nucifora S., Caleca V., Lo Verde G., Tortorici F., Rapisarda C., Bella S., 2018 - A review on introduced alien insect pests and their associated parasitoids on Eucalyptus trees in Sicily. - Redia, 101: 81-88. http://dx.doi.org/10.19263/REDIA-101.18.11

Wicken C.F., Couto E.B., Orlato C., Ferreira-Filho P.J., FIRMINo D.C., 2003 - Occorencia do psilideo-de-concha (Glycaspis brimblecombei) (Hemiptera: Psyllidae) em florestas de eucalipto do Brasil. - Circular Tecnica IPEF, 201: 1-11.

WiTHERS T.M., 2001 - Colonization of eucalypts in New Zealand by Australian insects. - Austral. Ecology, 26: 467476.

World Meteorological Organization, 2014 - Guide to Meteorological Instruments and Methods of Observation. - No.8. World Meteorological Organization, Geneva, Switzerland, $1128 \mathrm{pp}$. 